\title{
レアリストロヒンフ, 藥物學的研究補遺
}

\author{
㦄 煥 章 \\ (京都帝國大學醫學部藥物學敎室 [森島敎授])
}

（大正十五年七月二日受付）

緒論

實驗材料

I. 一般現象 $=$ 及ボス作用

I. 青蛙ニ於々ル實驗

2.レマウスフ二於タル實驗

3. 虾蚓二於ヶル實驗

4. 家鬼二於々ル實驗

5. 犬二於ゲル筫驗

II. 呼吸及血厴二及ボス作用

III. 心臟二及ボス作用

1. 截離セザル心臟ニ於々ル實驗

\section{内容目次}

2. 截離シタル心臟二於ふル實驗

IV. 青蛙骨骼筋二及ボ ス作用

V. 血管二及ボス作用

I. 青蛙後肢血管二於々ル實驗

2. 家鬼耳殼血管二於々ル實驗

VI. 摘出家鬼踢管二於々ル貫驗

VII. 摘出家兔子宮二於ヶル實驗

VIII. 切斷蚯蚓筋二於々儿實驗

IX. 總括及結論

文献

\section{緒論}

レアリストロヒンフ Aristolochin $\mathrm{C}_{32}-\mathrm{H}_{22} \mathrm{~N}_{2} \mathrm{O}_{13}$ ハI891 年 $P o h l^{1}$ ) ガ Aristolochia crematis, 成熟シタル種子及 Aristolochia rotunda ノ根ヨリ發見セルモノナリ。有毒性

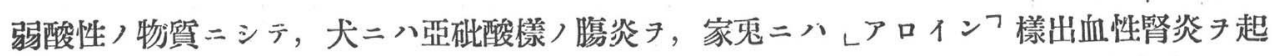

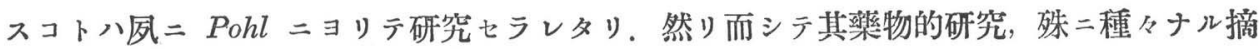

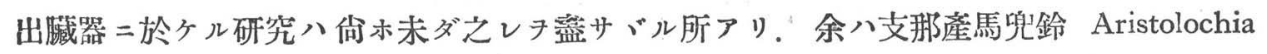

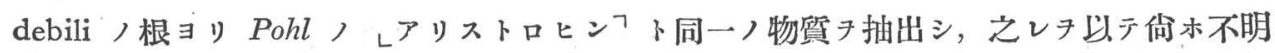
ナル樂物學的作用ノ研究キ企テタリ。

(備考 I895 年 Hesse ${ }^{2}$ ) ハ Aristolochia gentina ノ根ヨリ數種, 物質ヨ折出シ Pohl , レアリストロヒンフト全ク別固ノ物筫二同一)名稱キ與へPohl レアリストロヒンフニ 匹敵セル $\mathrm{C}_{15} \mathrm{H}_{11} \mathrm{~N} \mathrm{O}_{7}$ ナル集成キ有スル物質ニレアリストルフ酸 Aristolsäure ナル葐呼 
チ與へタリ。

馬㹸鈴八支那日本薹灣二於テ繁殖スル植物ニシテ，古來重要ナル藥品二屬シ，殊二毒 蛇, 咬傷二靈苝トシテ尊重セラル，其他民間治療藥トシテ咳嗽，痛風，子宮病，蜔䘄等，

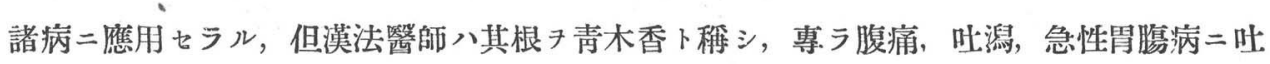

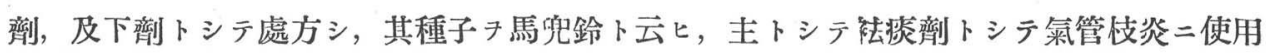
ス. 余八其種子二就テレアリストロヒンフタ檢出セザリシガ故ニ專ラ其根タ上ラ賽驗材料 製造ノ原料ト七リ。

\section{饆 驗 材 料}

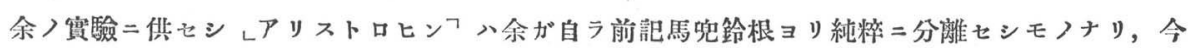

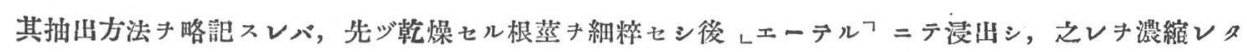

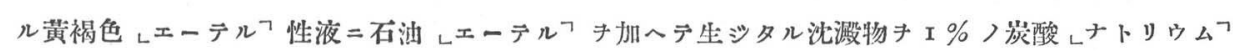

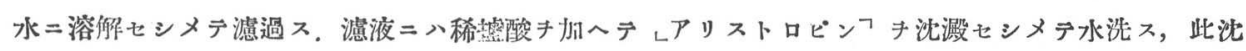

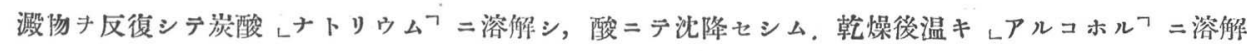

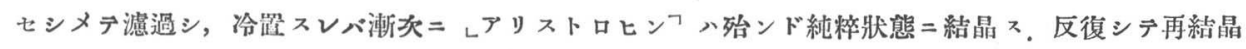

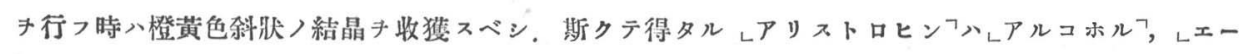

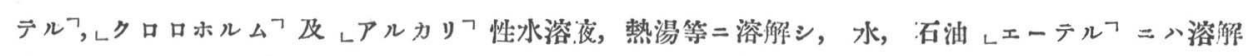
セズ, 之熱スレバ $23^{\circ} \mathrm{C}=$ 於テ褐色トナリ， $260^{\circ} \mathrm{C}=$ 至リテ融解セス゚シテ炭化ス。㧘素习含有シ, 酒精楁液ニハ酸性反應き呈シ, 味ハ極メテ苦シ。

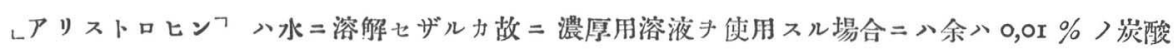

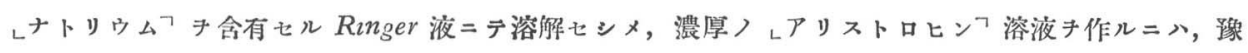

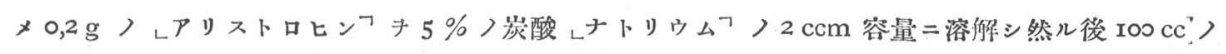

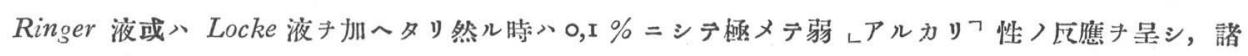

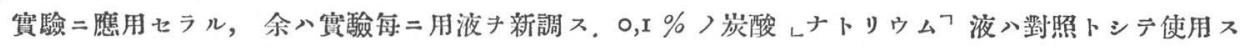
ルニ全り無害ナリ。

\section{I. 一般現象二及ボス作用}

1. 青蛙：致死量八體重 $10 \mathrm{~g}$ 二付 $2 \mathrm{mg}$ ナリ, 中等大ノ靑蛙ニレアリストロヒンフ 4 $m g$ ?腹部淋巴囊二注射スル二, 初メ八別二暴常ナク, 約 10 分後二八呼吸ハ不規則トナ

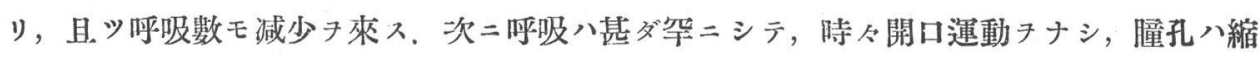
小ス。呼吸障害ト共二麻醉樣狀態二陷ル, 隨意運動ハ最初二八活潑ナレドモ, 漸次倦意 狀チ現ハス。他動的運動ハ初メ二八器械的刺戟二應ジテ飛跳スレドモ漸次迤鈍トナリ, 終 


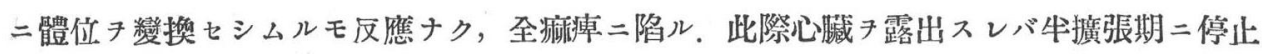

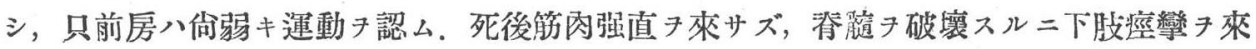

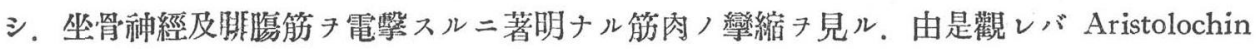
八蛙ノ中樞种經系及心藏二作用シ，之キ痳浑七シムルモノナリ。

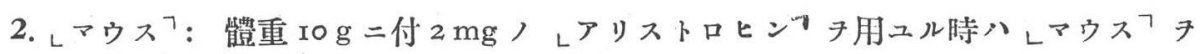
致死セシムべシ，即チ此分量ニテ皮下二注射スル時八約 5 分間ニシテ呼吸ハ促迫トナリ，

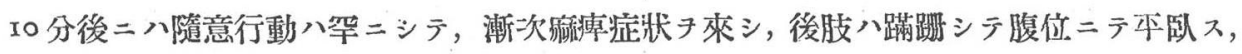

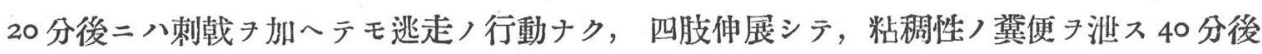

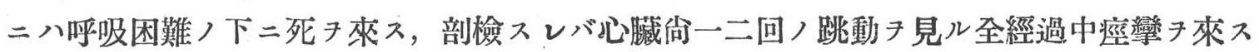

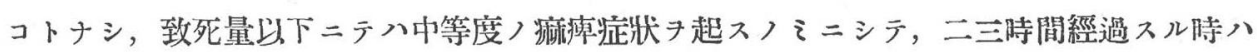
全ク恢復シ，運動再ビ活潑トナル。

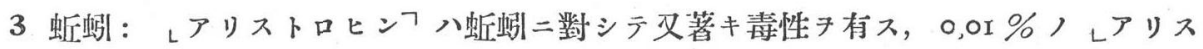
トロヒンフ溶液二浸漬セル虾蚓ハ浸漬後二三分間二ハ刺戟二對シ對照二比シ强キ反應子來

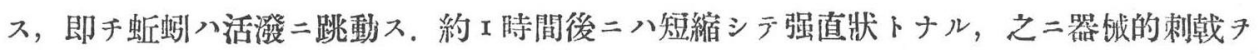
與フレバ倘劇烈ナル伸縮キ見ル。終二ハ强度ノ攣縮キ來シ，刺戟二對スル反動ハ甚ダ微弱 トナリ，約 4 洔間ノ經過ニテ運動全ク不能トナル。

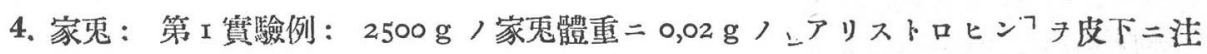

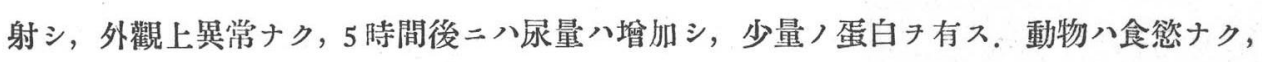

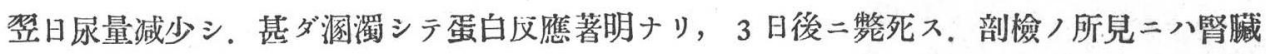

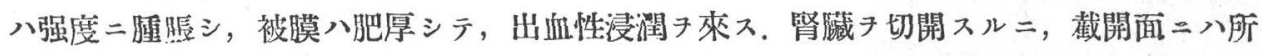
タニ出血部キ見ル。

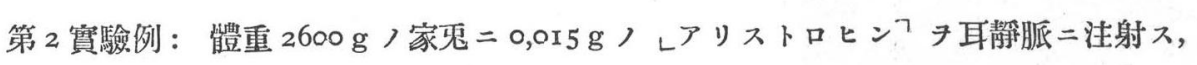

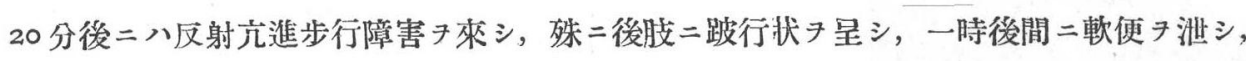
4,5 時間後二八殆ンド恢復ス。

第 3 實驗例：體重 $2300 \mathrm{~g}$ ，家鬼二0.03 g ノレアリストロヒンフォ耳靜脈內二注射ス.

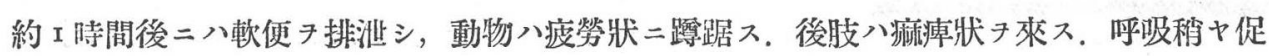
迫シ，心動减弱且ッ不規則トナリ。觕膜反應ナク，綮時ニシテ死キ來ス。

5. 犬：體重 $1000 \mathrm{~g}=$ 付 $0,01 \mathrm{~g}$ チ皮下二注射スルニ, 約 2 時間後二下粕便ヲ排泄ジ,

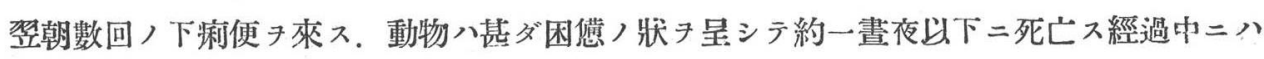




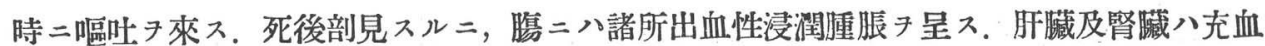
シ，䛈二腎臟二八默狀出血部諸所二散在ス。

\section{II. 呼吸及血壓二及ボス作用心嘁二及ボス作用}

レアリストロヒンフ，血壓二及ボス作用二就テハ，既二Pohl ハ犬二於テ血壓下降

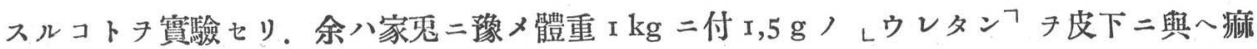

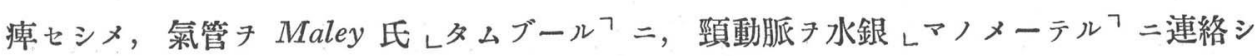
テ，呼吸及血壓キ同時二趈轉煤紙上二描出セシメツ、藥液 7 耳靜脈內二注射スルニ，其實 驗成績丹概括スレバ左ノ如シ。血壓》藥液注入後著キ昇膫キ來シ，數分後二再ビ常壓二下 リ。更二漸次下降シテ常壓ヨリ下行ス，呼吸八血壓上昇シ共二次第二正常二復歸ス。次二 豫メ迷走神經丹頸部兩侧二於テ切斷シ, 又八硫酸しアトロピンフォ以テ前處置セルモノニ 就テ，本毒物ヌ法射スル二，血壓八依然トシラ上昇ス．由是觀之レアリストロヒンフ八血 壓尹上昇セシムルモノニシテ，其原因ハ逃走神經系ト關係セズシテ，主トシテ末梢血管， 收縮ニ基クモノナラン. (V. 第 5 章參照)

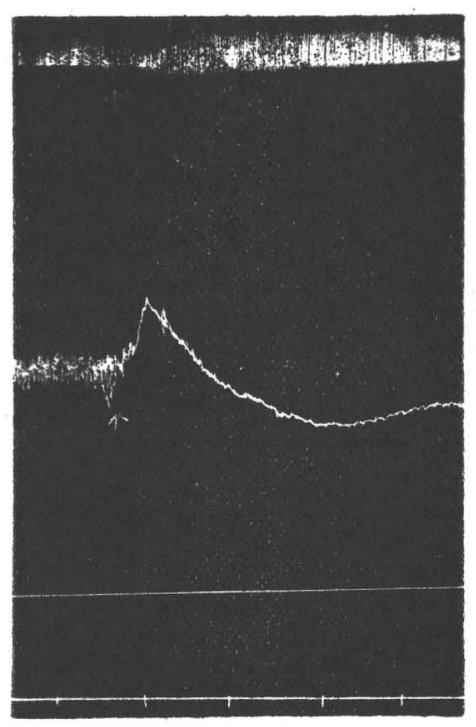

第 1 圖 呼吸及血厴曲線 合家鬼 2.200 瓦 レウレタンフ旅 醉. 0,2\% レアリストロヒンᄀ Io $\mathrm{ccm}$ 静脤注射。

\section{IIII.心臟二砐ボス作用}

1. 截離セザル心臟二於ケル賽驗ニょアリスト ロヒン 1 タ注射シタル青蛙ガホダ一般ノ完全㾁瘴タ 來ス前二, 若シ心䁍キ開慾シテ見レバ, 多クノ場合

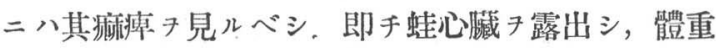
Io $\mathrm{g}$ 二付 $4 \mathrm{mg}$ ， レアリストロヒンフ チ注射スル時 八，先シ搏動ノ力及ビ數ノ减少丹認メ，遂二坐擴張

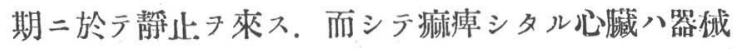
的刺戟及ビレアトロピンフノ滴下ニヨリテモ再ビ搏 動キ來サズ. 获ニ一例ヌ示セバ左ノ如シ.

體重 $20 \mathrm{~g}$ / 青蛙/ 心缄子露出七シメ, 其心搏動 數每 I 分間 38 チ算シ， レアリストロピンプ,008 $\mathrm{g}$ 丹 上腿淋巴囊二注射スルニ, I 5 分後二八心臟搏動數 32 トナリ. 心室ノ收縮ハ稍ヤ强盛ナレドモ擴張ハ少 
ク不完全ナルキ認ム． 30 分後二八其搏動數 25 トナリ。 45 分後二ハ搏動數 16 トナリ. 心 室ノ擴張不完全ナルチ來ス。 I 時間後二ハ心室ノ收縮數ふ7トナリ。心房ノ搏動數ハ其ノ 倍ナリ。I時間 30 分ノ後二八心室八牛擴張期二於テ静止尹來シ，心房二八佮ホ微弱ナル搏 動ヨ見ル。

2 , 截離シタル心藏二於ケル䁈驗：Straub 氏法二從七, レカニニーレフォ大動脈口ヨ

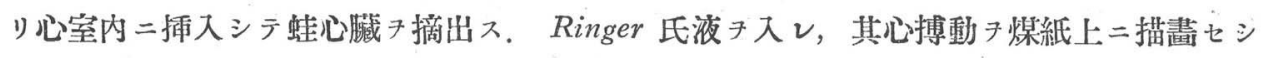

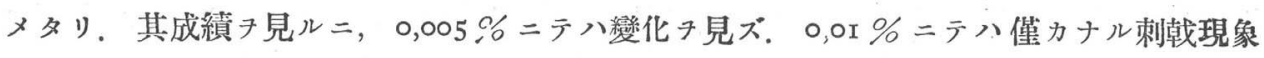

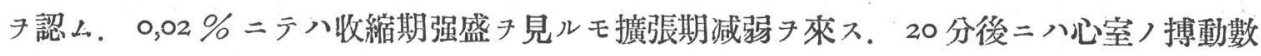
八减少シ，心房搏動ノ I/2 トナリ心室ノ收縮擴張い次第二緩慢且不完全トナリ。逐二不全 擴張期二於テ静止スルモ，心房八佮ホ搏動丹持續ス，此心臟靜止八しアトロピンフ及しス

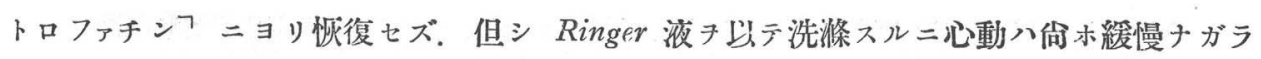
搏動シ，漸次恢復シテ以前ノ狀態トナルコトモアリ。0,04\%ニテハ心搏八直チニ减弱シ テ牛擴張期二於示停止ス. 此場合二ハRinger 氏液ョ以テ洗滌スルモ最早恢復チ來サズ. 凡テノ場合ニハレアトロピンフニヨリラ影響セラレズ. 上記ノ成績ニヨリレアリストロと ンフ 八直接二心藏筋肉二作用シテ全㾁㾝二陷ラシムルガ如シ, 對照トシテ 0,01 \% 炭酸レナ トリウムフ, 實驗ハ陰性ナリ。

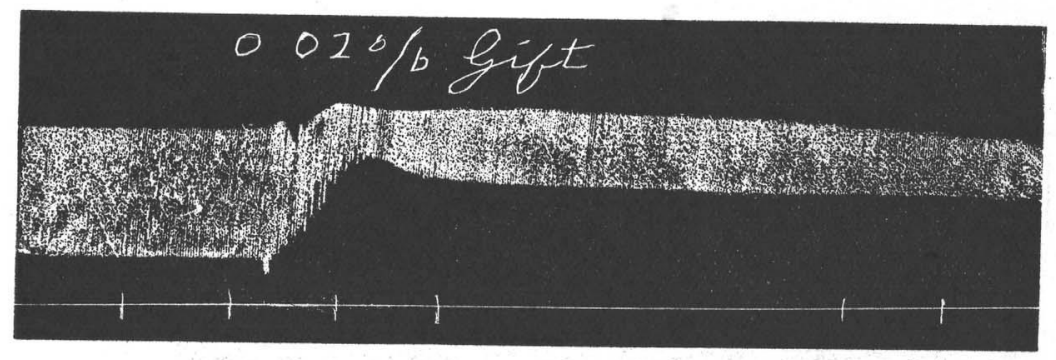

第 2 圆摘出毒蛙心歲曲線. $\downarrow 0,02 \%$ レアリフトロロヒン?

\section{IV． 青蛙骨骼筋二於ラル實驗}

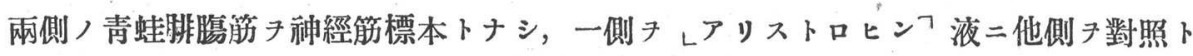

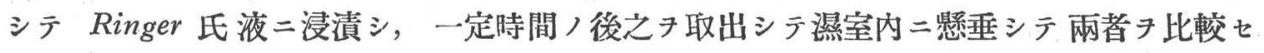

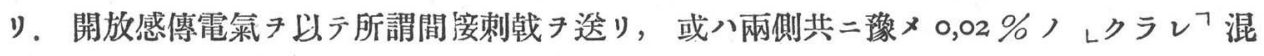

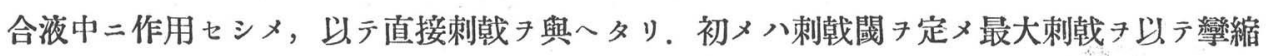


曲線尹，次二疲勞曲線尹描畫セシム。

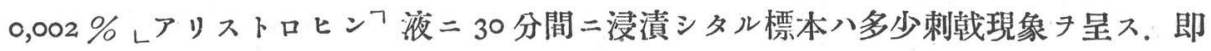
チ刺戟閾ハ小ニシテ攣縮曲線ハ大トナリ。疲勞曲線ハ瓲長ス。而シテ此濃度ノレアリスト ロヒンフ 液ニ I, 5 -2 時間浸漬シタル時八疲勞曲線ハ却ツテ短小トナル，0,005一 0,01 $\%$ ニテハ30分ノ浸漬ニテ既二卛縮曲線ハ小トナリ, 疲勞曲線モ短小トナルチ認ム. 若シ 2 時間モ浸漬シタル封ハ最早筋ノ興舊性ハ消失ス。 $0.03 \%$ 二テハ 30 分二テ既二筋ノ興奮 性消失シ，撩軸距離零二於ラモ反應キ來サズ.レクラレフォ以ラ處置シタルモノ、實驗八其 成績全ク間接刺戟ノ場合卜同樣ナリ。而シテ凡テノ場合二於テ大量ニテハ其曲線初メヨリ 低クナリ。筋ノ疲勞モ亦早ク，且ツ不規則トナル，此レ二由リラ゙見レバ， レアリストロヒ

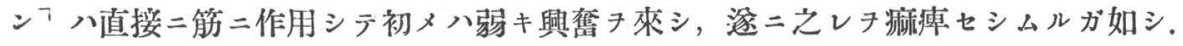

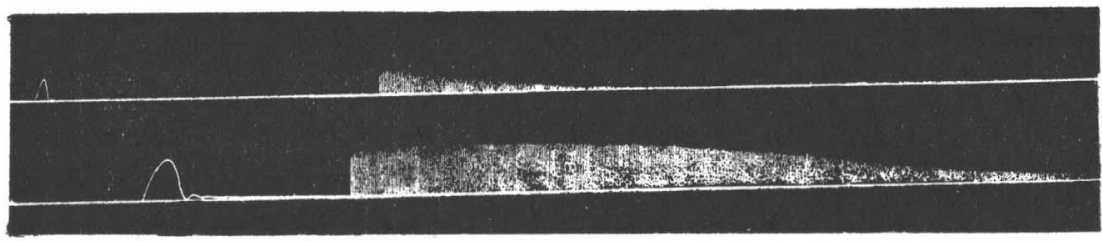

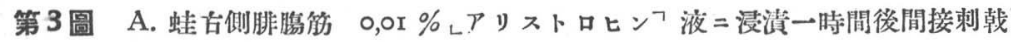
B. 蛙左側腓腹筋 對照

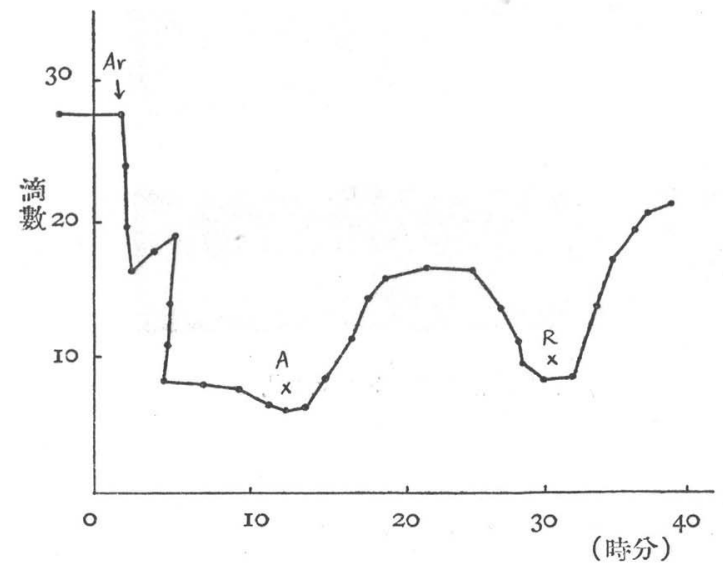

第 4 圖 青蛙後肢血管灌流賽驗。

Ar. $\downarrow 0,002 \%$ レアリストロヒンフ 液キ以テ灌 流 万.

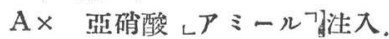

$\mathrm{R} \times$ 再ビレりんげる?液二テ灌流ス。

\section{V，血管二及ボフ作用}

1. 青蛙後肢血管二於ケル實驗： Laewen-Trendelenburg 氏法二則り， Ringer 液 Ð以テ灌流セル 青蛙後肢 血管二 $0,0005-0,001 \%$ ᄂアリ ストロヒンフォ灌流セシムルニ，滴 數ハ次第二減少キ來ス．若シ再ビ Ringer 淮キ以テ交換灌流スル時八 爻漸次以前, 正常滴數二復歸入。而 シテ血管收縮ノ强度及持續八凡テ藥 液ノ濃度二適應入。0,003\%ニテハ 滴數著ク减少シ, I 分間僅カ二ー, 二 
滴トナリ，此際 Ringer 液子交換灌流七シムル封八一是度绝八恢復スルモ，正常つ滴數二

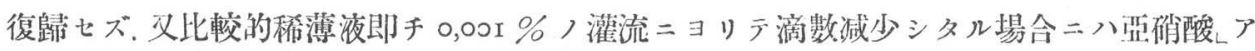
ミールフニヨリ抑制スルコトタ得ベシ.

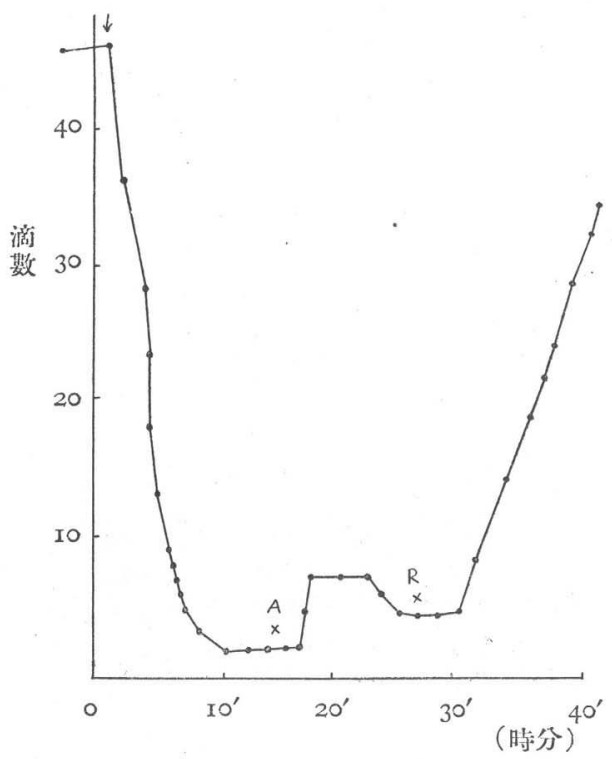

第 5 圖 家鬼耳款血管灌流實簽.

$\downarrow 0,003 \%$ レリストロヒンフ花灌流.

$A \times$ 亞㗂酸レアミッル? 注入.

$\mathrm{R} \times$ 再ピレりんげるフ 液灌流.

2. 芜否耳壳血管二於ケル䨘驗：

Krawkow-Pissemski 氏法二則り室温二於 $525 \mathrm{~cm}$ 水厴, $下=$ Ringer-Locke 氏液 キ以テ種々)濃度 $(0,00025,0,0005,0,0$ OI， 0,003，0,004\%）二溶解七シメテ貴 驗ス。其成續ハ總テノ埸合二於テ蛙後肢 血管灌流鲟驗ノ成績ト大差ナク，血管ノ

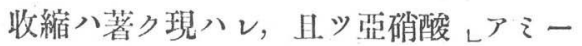
ルフニヨリ著ク抑制セラレズ.

\section{VI. 摘出家兔腸管二 於々ル鼻驗}

摘出シタル家鬼小腸入Magnus -

Fühner氏法二則リ $39^{\circ} \mathrm{C}=550 \mathrm{ccm}$ Locke 淮二營餋シ自發運動チナサシム。0,001\% ニテハ緊張ハ上昇ス. 此祭レアトロピンフ 添加ニヨルモ影響セラレズ。 0,003一0,005\%

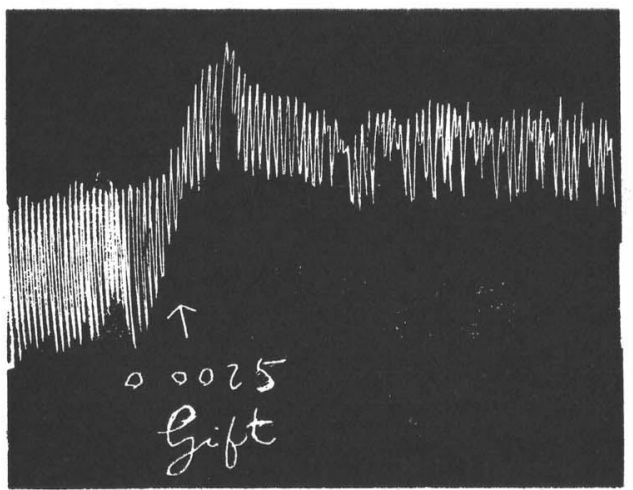

第 6 圆摘出家乘笏管。 $\uparrow \quad 0,0025 \%$ アリストロヒン .

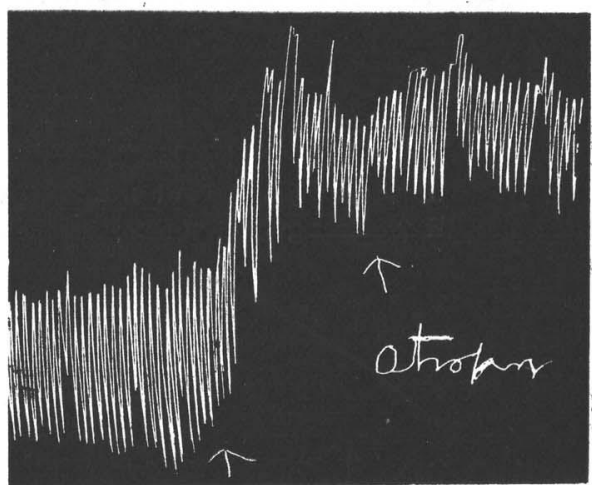

第 7 圖 摘出家兒膓管.

I. $\uparrow$ 0,0025\% .Pリストロヒン?. II. $\uparrow$ I \% 硫酸 レアトロピンフ $02 \mathrm{ccm}$. 
ニテハー過性ノ緊張上昇後沽次下降シ, 運動モ减弱ヌ來ス。此實驗ノ成績ニ徵スしバレア

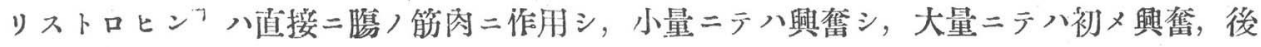
ニ八痛㽻セシムルガ如シ。

\section{VII. 摘出家兔子宮二於々ル貫驗}

本賽驗八寺トシラ不婎家鬼子宮子使用シ Magnus-Fühner 氏法二則り $39^{\circ} \mathrm{C} ニ テ L o c k e$

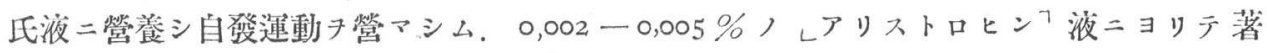
ク興奮キ來シ，即チ緊張八急二上昇シ，其頂上二於テ曲線ハ小ニシテ，强直性トナリ。此 際レアトロピンフノ添加ニヨリテモ影響セラレズ. 又旐メレアトロピンフタ以ラ前處置シ

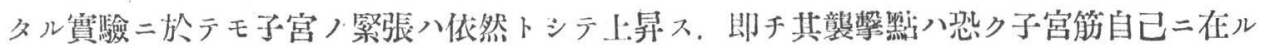
ガ如シ。

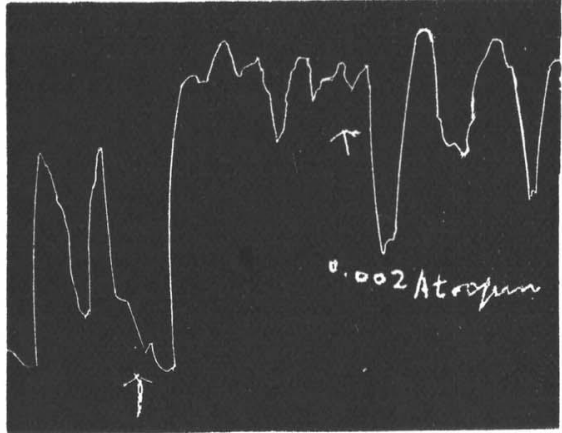

第 8 圖 摘淙冢鬼子宮.

I $\uparrow$ 0,006\% \%アリストロヒン.

II $\uparrow 0,002 \mathrm{~g}$ レアトロピン.

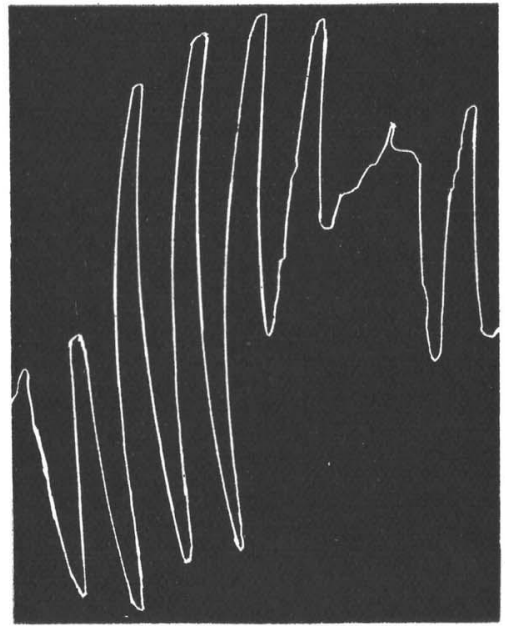

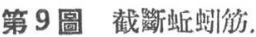

$\downarrow 0,05 \%$ レリストロヒン?.

\section{VIII．截斷蚯蚓筋二於与ル賽驗}

實驗法八前記家见腸及子宮)實噞卜同一ニシテ，只温度八室温ニ於テシ，營養液トシ ケ八蛙 Ringer 液子使用セリ，0,02一0,05\%) レアリストロヒンフニデ筋ノ緊張八速

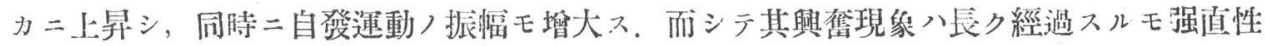


攣縮狀態二移行スルコトナシ， $0.1 \%$ テ ハ緊張高ク上昇シ, 自發運動八直チ二强直性状

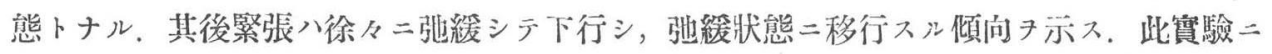
由レバレアリストロヒンフ 八虾蚂筋二對シテ見名興奮作用子强ク現ハスモノニシテ, 㾁㽻 作用ハ比較的輕微ナリ。

\section{IX。總 括 及結 諭}

レアリストロヒンフ Aristolochin $\mathrm{C}_{32} \mathrm{H}_{22} \mathrm{~N}_{2} \mathrm{O}_{13}$ 八弱酸阵ノ性質ニシ5, 凬二Pohl 氏

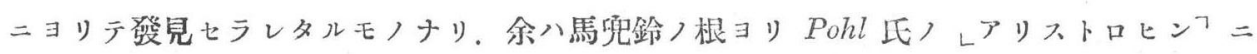
一致スルモノ子抽出シ, 結晶性ニシテ化學的純粹二精製シテ動物㙰驗用二供七り。其賽謌 成績キ概括スレバ下ノ如シ.

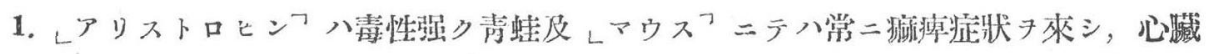

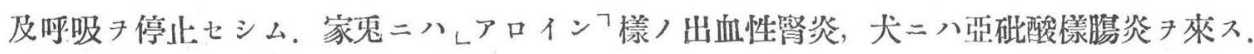

2. 蛙二於ケル致死量八體重 $10 \mathrm{~g}$ 二付約 $3 \mathrm{mg}$ レマウスフ 八體重 $10 \mathrm{~g}$ 二付約 $0,2 \mathrm{mg}$ 家 鬼欢犬二八艠重 $\mathrm{I} k \mathrm{~kg}$ 二付靜脈內二注射シテハ約 8- $10 \mathrm{mg}$ ナリ.

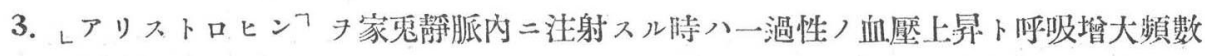
ア來シ，迷走紳經切斷ニテモしアトロピンフ，前處置ニテモ影響セラレズ.

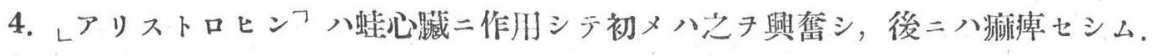

5. 末梢血管二對シテ八强收縮的二作用ス. 膓管及子宮二モ然リ，レアトロピンフニヨ リテ影響セラレズ，恐ラク筋自己テ犯スモノナラン。虾蜴筋テモ强ク刺战ス。

\section{文献}

I) Pohl, Arch. f. exp. Pakh. u. Pharmakol. Bd. 29, S. 282, I89I.

2) Hesse, Arch. d. Pharmaz. B1, 233. S. 684, I 895. 